\title{
Correction: Lupus community panel proposals for optimising clinical trials: 2018
}

Joan T Merrill, Susan Manzi, Cynthia Aranow, et al. Lupus community panel proposals for optimising clinical trials: 2018. Lupus Sci Med 2018;5:e000258. doi: 10.1136/ lupus-2018-000258.

The co-author, Anca Askanase's last name was spelled incorrectly as 'Askenase' in the published version.

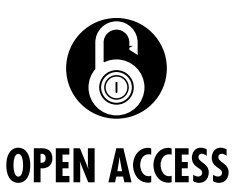

Open access This is an Open Access article distributed in accordance with the Creative Commons Attribution Non Commercial (CC BY-NC 4.0) license, which permits others to distribute, remix, adapt, build upon this work non-commercially, and license their derivative works on different terms, provided the original work is properly cited and the use is non-commercial. See: http://creativecommons.org/licenses/by-nc/4.0/

Lupus Sci Med 2018;5:e000258corr1. doi:10.1136/lupus-2018-000258corr1

A Check for updates 